\title{
Roseivivax lentus sp. nov., isolated from a tidal flat sediment, and emended description of the genus Roseivivax Suzuki et al. 1999
}

\author{
Sooyeon Park, So-Jung Kang, Tae-Kwang Oh and Jung-Hoon Yoon \\ Korea Research Institute of Bioscience and Biotechnology (KRIBB), PO Box 115, Yusong, Taejon, \\ Republic of Korea
}

Correspondence

Jung-Hoon Yoon

jhyoon@kribb.re.kr

\begin{abstract}
A Gram-negative-staining, aerobic, non-motile and rod-shaped bacterial strain, $55-5^{\top}$, was isolated from a tidal flat sediment at Saemankum on the west coast of Korea and subjected to a polyphasic taxonomic investigation. Strain $\mathrm{S} 5-5^{\top}$ grew optimally at $\mathrm{pH} 7.5-8.0$, at $30{ }^{\circ} \mathrm{C}$ and in the presence of $2 \%(\mathrm{w} / \mathrm{v}) \mathrm{NaCl}$. It did not produce bacteriochlorophyll a. Phylogenetic analyses based on $16 \mathrm{~S}$ rRNA gene sequences showed that strain $\mathrm{S} 5-5^{\top}$ is phylogenetically closely related to the genus Roseivivax, joining the cluster comprising the two recognized Roseivivax species. The 16S rRNA gene sequence similarity between strain $\mathrm{S} 5-5^{\top}$ and members of the genus Roseivivax was in the range 95.0-96.7\%. Strain S5-5 $5^{\top}$ contained Q-10 as the predominant ubiquinone and $\mathrm{C}_{18: 1} \omega 7 c$ and 11-methyl $\mathrm{C}_{18: 1} \omega 7 c$ as the major fatty acids. The DNA $\mathrm{G}+\mathrm{C}$ content was 68.2 mol\%. Differential phenotypic properties, together with the phylogenetic distinctiveness, demonstrated that strain $S 5-5^{\top}$ could be differentiated from Roseivivax species. On the basis of the data presented, strain $S 5-5^{\top}$ is considered to represent a novel species of the genus Roseivivax, for which the name Roseivivax lentus sp. nov. is proposed. The type strain is S5-5 $5^{\top}\left(=\right.$ KCTC $22708^{\top}=$ CCUG $\left.57755^{\top}\right)$.
\end{abstract}

The genus Roseivivax was proposed by Suzuki et al. (1999) with the descriptions of two bacteriochlorophyll (BChl) a-containing species, Roseivivax halodurans and Roseivivax halotolerans. No further Roseivivax species with validly published names have been described to date. Phylogenetic analyses based on 16S rRNA gene sequences show that the genus Roseivivax belongs to the family Rhodobacteraceae (Suzuki et al., 1999; Lee et al., 2005). The two Roseivivax species were isolated from a salt lake (Suzuki et al., 1999). In this study, we describe a bacterial strain, designated S5 $-5^{\mathrm{T}}$, which was isolated from a tidal flat sediment on the west coast of Korea. Comparative 16S rRNA gene sequence analysis indicated that strain $\mathrm{S} 5-5^{\mathrm{T}}$ is phylogenetically affiliated to the genus Roseivivax. The aim of the present work was to determine the exact taxonomic position of strain $\mathrm{S} 5-5^{\mathrm{T}}$ by using a polyphasic characterization that included the determination of chemotaxonomic and phenotypic properties and a detailed phylogenetic investigation based on $16 \mathrm{~S}$ rRNA gene sequences.

\section{Abbreviation: BChl, bacteriochlorophyll.}

The GenBank/EMBL/DDBJ accession number for the $16 \mathrm{~S}$ rRNA gene sequence of strain $\mathrm{S}^{-} \mathrm{5}^{\mathrm{T}}$ is $\mathrm{FJ} 875966$.

Photos of TLC plates showing polar lipids of strain $\mathrm{S} 5-5^{\top}$ and Roseivivax type strains are available as supplementary material with the online version of this paper.
Strain $55-5^{\mathrm{T}}$ was isolated by means of the dilution plating technique on marine agar 2216 (MA; Difco) at $25^{\circ} \mathrm{C}$. The type strains of the two recognized Roseivivax species were used as reference strains for phenotypic characterization and the analyses of fatty acids and polar lipids. $R$. halodurans KCTC $22255^{\mathrm{T}}$ was obtained from the Korean Collection for Type Cultures, Taejon, Korea, and R. halotolerans JCM $10271^{\mathrm{T}}$ was obtained from the Japan Collection of Microorganisms, Saitama, Japan. The morphological, physiological and biochemical characteristics of strain S5 $-5^{\mathrm{T}}$ were investigated using routine cultivation on MA at $30{ }^{\circ} \mathrm{C}$. Cell morphology was examined by using light microscopy (E600; Nikon) and transmission electron microscopy (CM-20; Philips). Flagellation was determined by using transmission electron microscopy with cells from exponentially growing cultures. Gliding motility was investigated as described by Bowman (2000). The Gram reaction was determined by using the bioMérieux Gramstain kit according to the manufacturer's instructions. Growth under anaerobic conditions was determined after incubation in a Forma anaerobic chamber on MA and on MA supplemented with $0.1 \%(\mathrm{w} / \mathrm{v})$ potassium nitrate, both of which had been prepared anaerobically under a nitrogen atmosphere. Growth at 4, 15, 20, 25, 30, 37, 40 and $45{ }^{\circ} \mathrm{C}$ was measured on MA. Growth in the absence of $\mathrm{NaCl}$ and in the presence of $0.5,1.0,2.0$ and $3.0 \%(\mathrm{w} / \mathrm{v}) \mathrm{NaCl}$ was investigated by using trypticase soy broth prepared 
according to the formula of the Difco medium except for supplementation with $0.45 \%(\mathrm{w} / \mathrm{v}) \mathrm{MgCl}_{2} .6 \mathrm{H}_{2} \mathrm{O}$ or $0.06 \%$ $(\mathrm{w} / \mathrm{v}) \mathrm{KCl}$ and exclusion or addition of $\mathrm{NaCl}$ as necessary. Growth at various $\mathrm{NaCl}$ concentrations $(2.0-15.0 \%$, w/v, in increments of $1.0 \%$ ) was investigated in marine broth 2216 (MB; Difco). The $\mathrm{pH}$ range for growth was determined in $\mathrm{MB}$ adjusted to $\mathrm{pH} 4.5-9.5$ (in increments of $0.5 \mathrm{pH}$ units) by the addition of $\mathrm{HCl}$ or $\mathrm{Na}_{2} \mathrm{CO}_{3}$. Catalase and oxidase activities were investigated as described by Cowan \& Steel (1965). Hydrolysis of casein, starch, hypoxanthine, xanthine and tyrosine was tested on MA using substrate concentrations described by Cowan \& Steel (1965). Hydrolysis of aesculin, gelatin, Tweens 20, 40, 60 and 80 and urea and reduction of nitrate were investigated as described by Lányí (1987) with the modification that artificial seawater $\left(1^{-1}\right.$ distilled water: $23.6 \mathrm{~g} \mathrm{NaCl}, 0.64 \mathrm{~g}$ $\mathrm{KCl}, 4.53 \mathrm{~g} \mathrm{MgCl}_{2} \cdot 6 \mathrm{H}_{2} \mathrm{O}, 5.94 \mathrm{~g} \mathrm{MgSO}_{4} .7 \mathrm{H}_{2} \mathrm{O}$ and $1.3 \mathrm{~g}$ $\mathrm{CaCl}_{2} \cdot 2 \mathrm{H}_{2} \mathrm{O}$; Bruns et al., 2001) was used for medium preparation. Cellulase and xylanase activities were investigated on MA containing $0.5 \%$ (w/v) CM-cellulose (Sigma) or xylan (Sigma), respectively, and detected according to the method of Teather \& Wood (1982). DNase activity was examined by using DNase test agar with methyl green (Difco) with the modification that artificial seawater was used for medium preparation. Acid production from carbohydrates was determined as described by Leifson (1963). Utilization of substrates as sole carbon and energy sources was tested as described by Baumann \& Baumann (1981), using supplementation with $2 \%$ (v/v) Hutner's mineral base (Cohen-Bazire et al., 1957) and $1 \%(\mathrm{v} / \mathrm{v})$ vitamin solution (Staley, 1968). $\mathrm{H}_{2} \mathrm{~S}$ production was tested as described by Bruns et al. (2001). Susceptibility to antibiotics was investigated on MA plates using antibiotic discs containing the following ( $\mu \mathrm{g}$ per disc unless otherwise stated): polymyxin B (100 U), streptomycin (50), penicillin G (20 U), chloramphenicol (100), ampicillin (10), cephalothin (30), gentamicin (30), novobiocin (5), tetracycline (30), kanamycin (30), lincomycin (15), oleandomycin (15), neomycin (30) and carbenicillin (100). Enzyme activities were determined after incubation for $4 \mathrm{~h}$ at $30{ }^{\circ} \mathrm{C}$ by using the API ZYM system (bioMérieux). Additional biochemical tests were performed using the API 20E system (bioMérieux); strips were inoculated with cells suspended in artificial seawater. For pigment absorption-spectrum analysis, strain $\mathrm{S} 5-5^{\mathrm{T}}$ was cultivated aerobically in the dark at $30{ }^{\circ} \mathrm{C}$ in MB. $R$. halodurans KCTC $22255^{\mathrm{T}}$ and $R$. halotolerans JCM $10271^{\mathrm{T}}$ were used as positive controls for the pigment absorption-spectrum analysis. The culture was centrifuged, washed twice using a MOPS buffer $(0.01 \mathrm{M}$ MOPS/NaOH, $\left.0.1 \mathrm{M} \mathrm{KCl,} 0.001 \mathrm{M} \mathrm{MgCl}_{2} ; \mathrm{pH} 7.5\right)$ and disrupted by sonication with a Branson 450 sonifier. After removal of cell debris by centrifugation, the absorption spectrum of the supernatant was determined with a Beckman Coulter DU800 spectrophotometer. An aliquot of the culture was also centrifuged, the pigments from the cells were extracted using acetone/methanol $(7: 2, \mathrm{v} / \mathrm{v})$ and the absorption spectrum of the pigments was determined with a Beckman Coulter DU800 spectrophotometer.
Cell biomass of strain $\mathrm{S} 5-5^{\mathrm{T}}$ for DNA extraction and for the analyses of isoprenoid quinones and polar lipids was obtained from cultures grown in $\mathrm{MB}$ at $30{ }^{\circ} \mathrm{C}$. Chromosomal DNA was extracted and purified by the procedure described by Yoon et al. (1996), with the modification that RNase $\mathrm{T} 1$ was used in combination with RNase A to minimize contamination with RNA. Amplification of the 16S rRNA gene sequence was performed using two universal primers as described previously (Yoon et al., 1998) and the PCR products were purified by using a QIAquick PCR purification kit (Qiagen). Sequencing of the amplified 16S rRNA gene and phylogenetic analysis were performed as described by Yoon et al. (2003). Isoprenoid quinones were analysed as described by Komagata \& Suzuki (1987), using reversedphase HPLC and a YMC ODS-A $(250 \times 4.6 \mathrm{~mm})$ column. Polar lipids were extracted according to the procedures described by Minnikin et al. (1984) and identified by twodimensional TLC followed by spraying with appropriate detection reagents (Minnikin et al., 1984; Komagata \& Suzuki, 1987). For cellular fatty acid analysis, cell mass of strain S5-5 ${ }^{\mathrm{T}}, \quad R$. halodurans KCTC $22255^{\mathrm{T}}$ and R. halotolerans JCM $10271^{\mathrm{T}}$ was harvested from MA plates after cultivation for 3 days at $30{ }^{\circ} \mathrm{C}$. The fatty acids were extracted and fatty acid methyl esters were prepared according to the standard protocol of the Microbial Identification System (Sasser, 1990). The DNA G+C content was determined using the method of Tamaoka \& Komagata (1984) with the modification that DNA was hydrolysed using nuclease P1 (Sigma) and the resultant nucleotides were analysed by reversed-phase HPLC.

The morphological, cultural, physiological and biochemical characteristics of strain $\mathrm{S} 5-5^{\mathrm{T}}$ are given in the species description and in Table 1. Strain $S 5-5^{\mathrm{T}}$ did not produce $\mathrm{BChl} a$ during aerobic growth in the dark. The $16 \mathrm{~S}$ rRNA gene sequence of strain $\mathrm{S} 5-5^{\mathrm{T}}$ determined in this study comprised 1385 nucleotides, representing approximately $96 \%$ of the Escherichia coli $16 \mathrm{~S}$ rRNA gene sequence. In the neighbour-joining phylogenetic tree based on $16 \mathrm{~S}$ rRNA gene sequences, strain $S 5-5^{\mathrm{T}}$ joined the cluster comprising the type strains of the two Roseivivax species with a bootstrap confidence level of $69.4 \%$, and this relationship was also maintained in the tree constructed using the maximum-likelihood algorithm (Fig. 1). Strain S5-5 exhibited 16S rRNA gene sequence similarity of 96.7 and $95.0 \%$ to $R$. halotolerans OCh $210^{\mathrm{T}}$ and $R$. halodurans $\mathrm{OCh}$ $239^{\mathrm{T}}$, respectively. The DNA G $+\mathrm{C}$ content of strain S5-5 ${ }^{\mathrm{T}}$ was $68.2 \mathrm{~mol} \%$.

The predominant ubiquinone detected in strain $\mathrm{S} 5-5^{\mathrm{T}}$ was ubiquinone-10 (Q-10), with a peak area ratio of approximately $93 \%$, which is the same as that of Roseivivax species (Suzuki et al., 1999). The cellular fatty acid profile of strain S5 $-5^{\mathrm{T}}$ is shown in Table 2 , in which the cellular fatty acid profiles of the two Roseivivax type strains analysed in this study are also given. The fatty acid profile of strain $\mathrm{S} 5-5^{\mathrm{T}}$ was similar with those of the Roseivivax type strains in that $\mathrm{C}_{18: 1} \omega 7 c$ is the predominant fatty acid, but there were also 
Table 1. Differential phenotypic characteristics of strain $S 5-5^{\top}$ and the type strains of Roseivivax species

Strains: 1 , Roseivivax lentus sp. nov. S5-5 $5^{\mathrm{T}} ; 2, R$. halodurans KCTC $22255^{\mathrm{T}} ; 3, R$. halotolerans $\mathrm{JCM} 10271^{\mathrm{T}}$. Data were taken from this study unless indicated. All three strains are Gram-negative-staining and positive for oxidase ${ }^{\star}$, catalase ${ }^{\star}$, hydrolysis of Tweens 20, 40 and 60 (weakly positive for R. halodurans JCM $10271^{\mathrm{T}}$ ), activity of alkaline phosphatase, esterase (C4), esterase lipase (C8), leucine arylamidase and naphthol-AS-BIphosphohydrolase and susceptibility to ampicillin, streptomycin, novobiocin, cephalothin, neomycin, carbenicillin, penicillin $\mathrm{G}$ and chloramphenicol. All three strains are negative for production of $\mathrm{H}_{2} \mathrm{~S}^{\star}$, hydrolysis of CM-cellulose, casein, DNA, starch ${ }^{\star}$, xanthine and xylan, acid production from D-sorbitol, myo-inositol, melezitose, trehalose, D-fructose, sucrose and raffinose, activity of lipase (C14), valine arylamidase, cystine arylamidase, trypsin, $\alpha$-chymotrypsin, $\alpha$-galactosidase, $\beta$-galactosidase, $\beta$-glucuronidase, $\alpha$-glucosidase, $\beta$-glucosidase, $N$-acetyl- $\beta$ glucosaminidase, $\alpha$-mannosidase and $\alpha$-fucosidase and susceptibility to polymyxin B and lincomycin. + , Positive; w, weakly positive; - , negative.

\begin{tabular}{|c|c|c|c|}
\hline Characteristic & 1 & 2 & 3 \\
\hline Colony colour on MA & Greyish yellow & Greyish yellow & Reddish orange \\
\hline Production of BChl $a$ & - & $+^{*}$ & $+^{*}$ \\
\hline $\mathrm{NaCl}$ range for growth (\%) & $2-13$ & $0-20^{*}$ & $0.5-20^{\star}$ \\
\hline Anaerobic growth & - & + & + \\
\hline Nitrate reduction & + & $+^{*}$ & $-{ }^{*}$ \\
\hline \multicolumn{4}{|l|}{ Hydrolysis of: } \\
\hline Aesculin & - & + & + \\
\hline Gelatin & - & $-{ }^{\star}$ & $+^{*}$ \\
\hline Hypoxanthine & - & + & + \\
\hline Tween 80 & + & - & - \\
\hline Tyrosine & - & + & + \\
\hline D-Galactose & - & + & $\mathrm{w}$ \\
\hline D-Glucose & - & + & - \\
\hline Lactose & - & + & - \\
\hline Maltose & - & + & - \\
\hline D-Mannitol & - & $\mathrm{w}$ & - \\
\hline D-Mannose & - & + & - \\
\hline Melibiose & - & + & - \\
\hline L-Rhamnose & - & $\mathrm{w}$ & - \\
\hline D-Ribose & - & + & - \\
\hline D-Xylose & - & + & - \\
\hline Acid phosphatase activity & - & - & + \\
\hline DNA G $+\mathrm{C}$ content $(\mathrm{mol} \%)$ & 68.2 & $64.4^{*}$ & $59.7^{\star}$ \\
\hline
\end{tabular}

${ }^{\star}$ Data for R. halodurans OCh $239^{\mathrm{T}}$ and R. halotolerans OCh $210^{\mathrm{T}}$ from Suzuki et al. (1999).

$\dagger$ AL, Unknown aminolipid; DPG, diphosphatidylglycerol; PE, phosphatidylethanolamine; PG, phosphatidylglycerol; PL, unidentified phospholipid; L, unidentified lipids.

differences in the proportions of some fatty acids, particularly $11-$ methyl $\mathrm{C}_{18: 1} \omega 7 c$ and $\mathrm{C}_{19: 0}$ cyclo $\omega 8 c$. The major polar lipids found in strain $S 5-5^{\mathrm{T}}$ were phosphatidylglycerol, phosphatidylethanolamine, an unidentified aminolipid, an unidentified phospholipid and two unidentified lipids (Table 1 and Supplementary Fig. S1, available in IJSEM Online). The polar lipid profiles of $R$. halodurans KCTC $22255^{\mathrm{T}}$ and $R$. halotolerans JCM $10271^{\mathrm{T}}$ were similar to that of strain $S 5-5^{\mathrm{T}}$ in that phosphatidylglycerol, phosphatidylethanolamine, an unidentified phospholipid and two unidentified lipids are the major polar lipids (Table 1 and Supplementary Fig. S1). An unidentified 


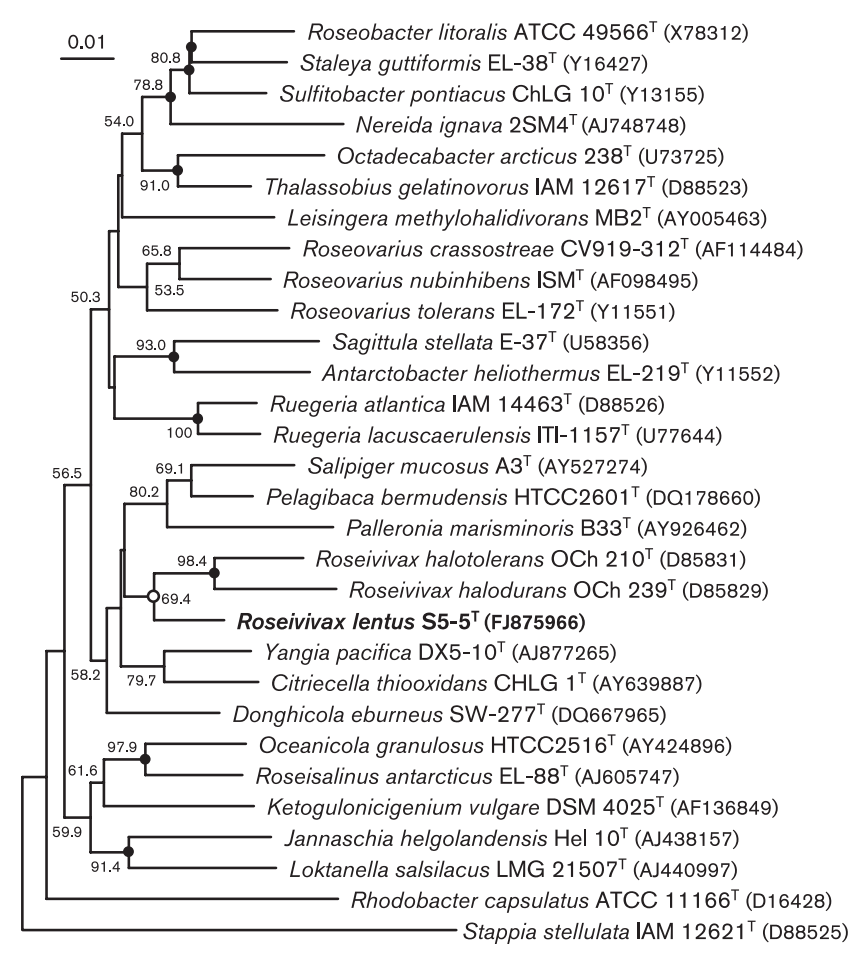

Fig. 1. Neighbour-joining tree based on $16 \mathrm{~S}$ rRNA gene sequences showing the positions of strain $\mathrm{S} 5-5^{\top}$, the type strains of the two Roseivivax species and some other related taxa. Bootstrap values ( $>50 \%$ ) based on 1000 replications are shown at branch nodes. Filled circles indicate that the corresponding nodes were also recovered in trees generated with the maximumlikelihood and maximum-parsimony algorithms. Open circles indicate that the corresponding node was also recovered in the tree generated with the maximum-likelihood algorithm. Stappia stellulata IAM $12621^{\top}$ was used as an outgroup. Bar, 0.01 substitutions per nucleotide position.

aminolipid was present as a major polar lipid in strain S5- $5^{\mathrm{T}}$ and $R$. halotolerans JCM $10271^{\mathrm{T}}$ but absent in R. halodurans KCTC $22255^{\mathrm{T}}$. A minor amount of diphosphatidylglycerol was detected in strain $\mathrm{S} 5-5^{\mathrm{T}}$ and $R$. halodurans KCTC $22255^{\mathrm{T}}$ but not detected in $R$. halotolerans JCM $10271^{\mathrm{T}}$. Differences in polar lipid profiles among members of the same genus have been reported many times. There were no distinct chemotaxonomic properties that served to differentiate strain $S 5-5^{\mathrm{T}}$ from the two recognized Roseivivax species. Accordingly, in view of the combined phylogenetic and chemotaxonomic data, it appears to be reasonable to classify strain $S 5-5^{\mathrm{T}}$ within the genus Roseivivax.

The phylogenetic distinctiveness is sufficient to categorize strain $\mathrm{S} 5-5^{\mathrm{T}}$ as a member of a species that is distinct from the recognized Roseivivax species (Stackebrandt \& Goebel, 1994). Strain $\mathrm{S} 5-5^{\mathrm{T}}$ is also distinguishable from Roseivivax species by differences in phenotypic characteristics, including colony colour, presence of flagella, production of $\mathrm{BChl}$ $a$, susceptibility to antibiotics and hydrolysis of, utilization
Table 2. Cellular fatty acid compositions of strain $S 5-5^{\top}$ and the type strains of Roseivivax species

Strains: 1, Roseivivax lentus sp. nov. S5-5 ${ }^{\mathrm{T}} ; 2$, R. halodurans KCTC $22255^{\mathrm{T}} ; 3$, R. halotolerans JCM $10271^{\mathrm{T}}$. Values are percentages of total fatty acids, obtained in this study. Fatty acids that represented $<0.5 \%$ in all strains were omitted. -, Not detected.

\begin{tabular}{|lccc|}
\hline Fatty acid & $\mathbf{1}$ & $\mathbf{2}$ & $\mathbf{3}$ \\
\hline Straight-chain & & & \\
$\mathrm{C}_{16: 0}$ & 6.5 & 6.4 & 2.9 \\
$\mathrm{C}_{17: 0}$ & 3.2 & 0.8 & 0.2 \\
$\mathrm{C}_{18: 0}$ & 4.8 & 7.8 & 4.2 \\
Branched & & & \\
iso- $\mathrm{C}_{15: 0}$ & - & 0.9 & - \\
Unsaturated & & & \\
$\mathrm{C}_{18: 1} \omega 7 c$ & 68.2 & 59.1 & 69.7 \\
$\mathrm{C}_{20: 1} \omega 7 c$ & 0.3 & 0.3 & 1.1 \\
$\mathrm{C}_{20: 2} \omega 6,9 c$ & - & 1.3 & - \\
Hydroxy & & & \\
$\mathrm{C}_{10: 0} 3-\mathrm{OH}$ & 1.2 & - & 0.2 \\
$\mathrm{C}_{12: 0} 3-\mathrm{OH}$ & 0.5 & 3.3 & 2.1 \\
$\mathrm{C}_{12: 1} 3-\mathrm{OH}$ & 1.0 & - & 1.5 \\
$\mathrm{C}_{19: 0}$ cyclo $\omega 8 c$ & 2.4 & 15.7 & 12.8 \\
$11-\mathrm{Methyl} \mathrm{C}_{18: 1} \omega 7 c$ & 10.7 & 3.8 & 3.9 \\
Summed feature $7^{\star}$ & 0.2 & - & 1.0 \\
\hline
\end{tabular}

*Summed features represent groups of two or three fatty acids that cannot be separated by the Microbial Identification System. Summed feature 7 consisted of one or more of $\mathrm{C}_{19: 1} \omega 6 c, \mathrm{C}_{19: 0}$ cyclo $\omega 10 c$ and an unknown fatty acid (equivalent chain-length 18.846).

of and acid production from various substrates (Table 1). Therefore, on the basis of the phenotypic, chemotaxonomic and phylogenetic data, strain $\mathrm{S} 5-5^{\mathrm{T}}$ is considered to represent a novel species of the genus Roseivivax, for which the name Roseivivax lentus sp. nov. is proposed.

\section{Emended description of the genus Roseivivax Suzuki et al. 1999}

The description of the genus Roseivivax is as given by Suzuki et al. (1999) with the following amendments. Motile or non-motile. BChl a may or may not be produced. Anaerobic growth may or may not occur. Common major polar lipids are phosphatidylglycerol, phosphatidylethanolamine, an unidentified phospholipid and unidentified lipids. The DNA G $+\mathrm{C}$ content is $59.7-68.2 \mathrm{~mol} \%$.

\section{Description of Roseivivax lentus sp. nov.}

Roseivivax lentus (len'tus. L. masc. adj. lentus slow, delayed, referring to the slow growth of the micro-organism).

Cells are Gram-negative-staining, aerobic, non-flagellated, non-gliding and rod-shaped, $0.5-1.0 \mu \mathrm{m}$ in diameter and 1.0-3.0 $\mu \mathrm{m}$ long. Colonies on MA are circular, slightly convex, glistening, smooth and greyish yellow. Optimal growth temperature is $30{ }^{\circ} \mathrm{C}$; growth occurs at 10 and 
$40{ }^{\circ} \mathrm{C}$, but not at 4 or $45{ }^{\circ} \mathrm{C}$. Optimal $\mathrm{pH}$ for growth is between $\mathrm{pH} 7.5$ and 8.0; growth occurs at $\mathrm{pH}$ 5.5, but not at $\mathrm{pH}$ 5.0. Growth occurs in the presence of 2.0-13.0\% (w/v) $\mathrm{NaCl}$ with an optimum of approximately $2.0 \%(\mathrm{w} / \mathrm{v}) \mathrm{NaCl}$. $\mathrm{BChl} a$ is not produced. D-Fructose, D-galactose, D-glucose, acetate, succinate, L-malate and L-glutamate are utilized as sole carbon and energy sources, but L-arabinose, cellobiose, maltose, D-mannose, sucrose, trehalose, D-xylose, citrate, benzoate, pyruvate, salicin and formate are not. The predominant ubiquinone is Q-10. The major polar lipids are phosphatidylglycerol, phosphatidylethanolamine, an unidentified aminolipid, an unidentified phospholipid and two unidentified lipids. The major cellular fatty acids $(>10 \%$ of total fatty acids) are $\mathrm{C}_{18: 1} \omega 7 c$ and 11-methyl $\mathrm{C}_{18: 1} \omega 7 c$. Other phenotypic characteristics are given in Table 1 . The DNA G $+\mathrm{C}$ content of the type strain is $68.2 \mathrm{~mol} \%$ (determined by HPLC).

The type strain, S5-5 $5^{\mathrm{T}}\left(=\mathrm{KCTC} 22708^{\mathrm{T}}=\right.$ CCUG $57755^{\mathrm{T}}$ ), was isolated from a tidal flat sediment at Saemankum on the west coast of Korea.

\section{Acknowledgements}

This work was supported by the 21C Frontier Program of Microbial Genomics and Applications (grant MG05-0401-2-0) from the Ministry of Education, Science and Technology (MEST) of the Republic of Korea.

\section{References}

Baumann, P. \& Baumann, L. (1981). The marine Gram-negative eubacteria: genera Photobacterium, Beneckea, Alteromonas, Pseudomonas, and Alcaligenes. In The Prokaryotes, pp. 1302-1331. Edited by M. P. Starr, H. Stolp, H. G. Trüper, A. Balows \& H. G. Schlegel. Berlin: Springer.

Bowman, J. P. (2000). Description of Cellulophaga algicola sp. nov., isolated from the surfaces of Antarctic algae, and reclassification of Cytophaga uliginosa (ZoBell and Upham 1944) Reichenbach 1989 as Cellulophaga uliginosa comb. nov. Int J Syst Evol Microbiol 50, 18611868.

Bruns, A., Rohde, M. \& Berthe-Corti, L. (2001). Muricauda ruestringensis gen. nov., sp. nov., a facultatively anaerobic, appendaged bacterium from German North Sea intertidal sediment. Int $J$ Syst Evol Microbiol 51, 1997-2006.
Cohen-Bazire, G., Sistrom, W. R. \& Stanier, R. Y. (1957). Kinetic studies of pigment synthesis by nonsulfur purple bacteria. J Cell Comp Physiol 49, 25-68.

Cowan, S. T. \& Steel, K. J. (1965). Manual for the Identification of Medical Bacteria. London: Cambridge University Press.

Komagata, K. \& Suzuki, K. (1987). Lipid and cell-wall analysis in bacterial systematics. Methods Microbiol 19, 161-207.

Lányi, B. (1987). Classical and rapid identification methods for medically important bacteria. Methods Microbiol 19, 1-67.

Lee, K.-B., Liu, C.-T., Anzai, Y., Kim, H., Aono, T. \& Oyaizu, H. (2005). The hierarchical system of the 'Alphaproteobacteria': description of Hyphomonadaceae fam. nov., Xanthobacteraceae fam. nov. and Erythrobacteraceae fam. nov. Int J Syst Evol Microbiol 55, 1907-1919.

Leifson, E. (1963). Determination of carbohydrate metabolism of marine bacteria. J Bacteriol 85, 1183-1184.

Minnikin, D. E., O'Donnell, A. G., Goodfellow, M., Alderson, G., Athalye, M., Schaal, A. \& Parlett, J. H. (1984). An integrated procedure for the extraction of bacterial isoprenoid quinones and polar lipids. J Microbiol Methods 2, 233-241.

Sasser, M. (1990). Identification of bacteria by gas chromatography of cellular fatty acids, MIDI Technical Note 101. Newark, DE: MIDI Inc.

Stackebrandt, E. \& Goebel, B. M. (1994). Taxonomic note: a place for DNA-DNA reassociation and 16S rRNA sequence analysis in the present species definition in bacteriology. Int J Syst Bacteriol 44, 846849.

Staley, J. T. (1968). Prosthecomicrobium and Ancalomicrobium: new prosthecate freshwater bacteria. J Bacteriol 95, 1921-1942.

Suzuki, T., Muroga, Y., Takahama, M. \& Nishimura, Y. (1999). Roseivivax halodurans gen. nov., sp. nov. and Roseivivax halotolerans sp. nov., aerobic bacteriochlorophyll-containing bacteria isolated from a saline lake. Int J Syst Bacteriol 49, 629-634.

Tamaoka, J. \& Komagata, K. (1984). Determination of DNA base composition by reversed-phase high-performance liquid chromatography. FEMS Microbiol Lett 25, 125-128.

Teather, R. M. \& Wood, P. J. (1982). Use of Congo red-polysaccharide interactions in enumeration and characterization of cellulolytic bacteria from the bovine rumen. Appl Environ Microbiol 43, 777-780.

Yoon, J.-H., Kim, H., Kim, S.-B., Kim, H.-J., Kim, W. Y., Lee, S. T., Goodfellow, M. \& Park, Y.-H. (1996). Identification of Saccharomonospora strains by the use of genomic DNA fragments and rRNA gene probes. Int J Syst Bacteriol 46, 502-505.

Yoon, J.-H., Lee, S. T. \& Park, Y.-H. (1998). Inter- and intraspecific phylogenetic analysis of the genus Nocardioides and related taxa based on 16S rDNA sequences. Int J Syst Bacteriol 48, 187-194.

Yoon, J.-H., Kim, I.-G., Shin, D.-Y., Kang, K. H. \& Park, Y.-H. (2003). Microbulbifer salipaludis sp. nov., a moderate halophile isolated from a Korean salt marsh. Int J Syst Evol Microbiol 53, 53-57. 